\title{
Life history traits of the exotic freshwater snail Melanoides tuberculata Müller, 1774 (Gastropoda, Thiaridae), and its sensitivity to common stressors in freshwaters
}

Ciclo de vida do caramujo exótico de água doce Melanoides tuberculata Müller, 1774 (Gastropoda, Thiaridae), e sua sensibilidade a estressores físico-químicos

\section{Denise Tieme Okumura ${ }^{1 *}$ (D) and Odete Rocha ${ }^{2}$}

${ }^{1}$ Escola de Engenharia de São Carlos, Universidade de São Paulo - USP, Av. Trabalhador São-carlense, 400, CEP 13566-590, São Carlos, SP, Brasil

${ }^{2}$ Departamento de Ecologia e Biologia Evolutiva, Centro de Ciências Biológicas e da Saúde, Universidade Federal de São Carlos - UFSCar, Via Washington Luis, Km 235, CEP 13565-905, São Carlos, SP, Brasil

*e-mail: detiok@gmail.com

Cite as: Okumura, D.T. and Rocha, O. Life history traits of the exotic freshwater snail Melanoides tuberculata Müller, 1774 (Gastropoda, Thiaridae), and its sensitivity to common stressors in freshwaters. Acta Limnologica Brasiliensia, 2020, vol. 32, e19.

Abstract: Aim: In the present study has analyzed several aspects of the life history traits of Melanoides tuberculata, an exotic species, under laboratory conditions, and its response to some stressors has also been applied. Methods: Sensitivity to two toxic substances was tested. The mollusks were collected and cultured in the laboratory under controlled conditions of temperature of $25 \pm 1{ }^{\circ} \mathrm{C}$ and $\mathrm{ad}$ libitum food regime. Growth rates and biomass were experimentally obtained and the individual growth curve obtained. Results: The experiment lasted 287 days and the maximum shell lengths registered was $11.67 \mathrm{~mm}$. The growth curve indicated a rate of $3.98 \mathrm{year}^{-1}$ and a maximum theoretical length of $10.61 \mathrm{~mm}$. The mean post-embrionary development time until first reproduction was 275 days and the size of the primipara was $10.13 \mathrm{~mm}$. An accelerated growth of juveniles was observed with fast increase in the shell length until sexual maturity, but growth rate decreased afterwards as more energy was devoted to reproduction. Under the combination of $25^{\circ} \mathrm{C}$ and fed on alternate days, $M$. tuberculata had a slow growth and a long-life expectancy under laboratory conditions. The tolerance of this mollusk to temperature as a stressor ranged between $16^{\circ} \mathrm{C}$ and $37^{\circ} \mathrm{C}$, being the optimum temperature situated between $29^{\circ} \mathrm{C}$ and $34^{\circ} \mathrm{C}$. The $\mathrm{LC}(\mathrm{I}) 50-24 \mathrm{~h}$ for reference substances were: $0.70 \mathrm{~g} \mathrm{~L}^{-1}$ for $\mathrm{KCl}$ and $9.05 \mathrm{~g} \mathrm{~L}^{-1}$ for $\mathrm{NaCl}$. Conclusion: Based on these results, we can conclude that $M$. tuberculata is a species tolerant to temperature and salinity, what partially explains to accordance to its wide and rapid dispersion throughout tropical waters.

Keywords: life cycle; laboratory conditions; growth; invasive mollusc; toxicity tests.

Resumo: Objetivo: No presente estudo foram analisados diversos aspectos do ciclo de vida de Melanoides tuberculata, um gastrópode exótico, sob condições controladas em laboratório, e, também foram avaliados a sua resposta a alguns estressores. Métodos: Foram testadas a sensibilidade a duas substâncias tóxicas. Os moluscos foram coletados e cultivados em laboratório sobre condiçóes controladas de temperatura de $25 \pm 1{ }^{\circ} \mathrm{C}$ e alimentação ad libitum. A taxa de crescimento e as relaçóes peso-comprimento foram determinadas, além da curva de crescimento individual. Resultados: A duraçáo do experimento foi de 287 dias, os valores de comprimentos máximo da concha foi de 
11,67 mm. Os parâmetros da curva de crescimento revelaram taxa de crescimento de 3,98 ano ${ }^{-1}$ e comprimento máximo teórico de $10,61 \mathrm{~mm}$. Em média $M$. tuberculata apresentou a primípara em 275 dias com comprimento de $10,13 \mathrm{~mm}$. O crescimento foi mais acentuado na fase juvenil decorrente do maior investimento nesta fase para a formação da concha até a maturidade sexual, após isso houve redução nas taxas de crescimento para maior investimento de energia na reprodução. Assim, M. tuberculata apresentou crescimento lento e uma longa expectativa de vida em condiçóes laboratoriais. A faixa de tolerância à temperatura de $M$. tuberculata situa-se entre $16{ }^{\circ} \mathrm{C}$ e $37^{\circ} \mathrm{C}$, sendo a faixa ótima de temperatura entre $29^{\circ} \mathrm{C}$ e $34^{\circ} \mathrm{C}$. A CL(I) 50-24h foram: 0,70 g.L - $^{-1}$ para $\mathrm{KCl}$ e 9,05 g. $\mathrm{L}^{-1}$ para $\mathrm{NaCl}$. Conclusóes: Baseados nestes resultados podemos concluir que $M$. tuberculata é uma espécie tolerante a temperatura e salinidade, o que explicaria parcialmente sua ampla e rápida dispersão em águas tropicais.

Palavras-chave: ciclo de vida; condiçôes de laboratório; crescimento; molusco invasor; testes de toxicidade.

\section{Introduction}

Studies on the life history traits of invasive mollusks are relevant to subsidize management and control actions since it has been shown they can cause great economical losses (Mead, 1979), extinguish endemic elements of faunas (Civeyrel \& Simberloff, 1996) and be vectors of human parasites (Malek, 1980). According to Fernandez et al. (2003), especially the native species in South America freshwaters have suffered with numerous invasions by exotic species of mollusks in recent years as happened with Corbicula fluminea Müller, 1774 (Corbiculidae, Bivalvia), Limnoperna fortunei Dunker, 1857 (Mytilidae, Bivalvia) and Melanoides tuberculata Müller, 1774 (Thiaridae, Gastropoda).

$M$. tuberculata is native to North and East Africa, Southeast Asia, China and some Indo-Pacific islands, with wide distribution on these areas (Madsen \& Frandsen, 1989). In Brazil it was first recorded in the city of Santos around 1967, and since then it has spread to many other regions in the country (Vaz et al., 1986; Abílio, 1997). There are evidences suggesting that the introduction was accidental, probably attached to aquatic plants and ornamental fishes brought by aquarists or fish-farmers (Fernandez et al., 2003). Later this species was intentionally transferred to other regions in the country for biological control as competitors of mollusks vectors of human diseases, particularly species of the Planorbidae family (Guimarães et al., 2001; Giovanelli et al., 2002). Nevertheless, little is known on the effects of $M$. tuberculata upon the native malacofauna in places where this species was introduced.

Literature records show that $M$. tuberculata is extensively invading aquatic ecosystems in the Neotropics, evidencing its high migratory and adaptive capacity. It already became well established in many types of habitats (Pointier et al., 1993; Supian \& Ikhwanuddin, 2002). The invasion of the natural lakes of Rio Doce valley, State of Minas Gerais, and the large reservoirs of Tietê river in São Paulo State is well documented (Dornfeld et al., 2004; Suriani et al., 2007). In Salto Grande reservoir, a water body located in Americana, SP and connected to Tietê River Pamplin (1999) recorded $M$. tuberculata as the only mollusk occurring in benthic community, evidencing the negative effect of this invader mollusk on aquatic wildlife.

Another factor that must be considerate is that the $M$. tuberculata itself can be a vector of waterborne diseases such as clonorchiasis and paragonimiasis being the first intermediate host of Clonorchis sinensis Looss, 1907, the chinese liver fluke, and of Paragonimus westermani Kerbert, 1878, the oriental lung fluke, respectively (Malek $\&$ Cheng, 1974). The Brazilian sanitation institute Adolfo Lutz long ago recorded the occurrence of clonorchiasis between immigrants installed in Brazil in 1975 (Vaz et al., 1986). In addition, recent reports of $M$. tuberculata infected with larval trematodes (rediae and pleurolophocercous cercariae) were published by Boaventura et al. (2002) in Guapimirim Maricá, RJ, and by Bogéa et al. (2005) in several areas of the metropolitan region of Rio de Janeiro.

M. tuberculata is widespread in the Old World tropics where it inhabits a wide range of freshwater habitats. Consequently, some variation in life cycle of this species could be anticipated. Indeed, such local adaptations have been recorded in less cosmopolitan freshwater snail species (Calow, 1981). Adaptation of M. tuberculata to local conditions could be brought about due to environmental influences producing ecophenotypic alterations (Fryer et al., 1983).

The present study aimed to get a deeper knowledge on the biology of the exotic mollusk $M$. tuberculata grown in the laboratory in order to provide a basis for management actions. The control of this invasive species will require the development 
of a specific plan of action combining many different control strategies.

\section{Material and Methods}

Specimens of $M$. tuberculata were collected in artificial ponds at the National Center for Research and Conservation of Continental Aquatic Biodiversity (CEPTA/ ICMBio), located at Pirassununga municipality, São Paulo State, Brazil. At the time of specimen collection, performed in June 2004, authorization for sampling invertebrates was not required.

Twenty to thirty individuals of $M$. tuberculata were placed in aquarium containing reconstituted water, sand substrate and the macrophytes Pistia stratiotes L., 1753 and Salvinia auriculata Aubl., 1775 under constant temperature of $25 \pm 1{ }^{\circ} \mathrm{C}$. Culture medium was a mixture of reconstitute and natural pond water from Monjolinho reservoir (between the parallels $21^{\circ} 57^{\prime} \mathrm{S}$ and $47^{\circ} 50^{\prime} \mathrm{W}$ ) in a 6:1 ratio. Main characteristics of this medium were: 40-44 $\mathrm{mg} \mathrm{CaCO}_{3} \mathrm{~L}^{-1}$ total hardness and 7.0-7.6 $\mathrm{pH}$. Culture medium was replaced twice a week and mollusks were fed each other day with a mixture of dried lettuce and Tetramin ${ }^{\otimes}$ fish ration in powder.

Growth experiments started with 10 newly born mollusks aged 2-4 days and $1.5-3.5 \mathrm{~cm}$ length. They were kept isolates in $300 \mathrm{~mL}$ plastic recipients under constant temperature of $25^{\circ} \mathrm{C}$ and 12:12 hours light/ dark cycle in a B.O.D. incubator. Each recipient contained sand substrate and one P. stratiotes individual, plus the culture medium.

Initial mollusk lengths were measured under the Wild Heerbrugg stereomicroscope until they reached $1.0 \mathrm{~cm}$ and thereafter with pachymeter. Total lengths of the shell were taken from the top of the shell until the vertex end. Measurements of total shell length, operculum diameter and greatest shell width were performed twice a week, at the time the medium was replaced and animals fed. Individual sizes were plotted against time and the growth curve was fitted using the von Bertalanffy (1938) model.

Individual biomass values were determined by weighting 30 individuals of different size classes. Each organism was initially weighed (fresh weight), placed in previously weighed pans, dried in oven at $60{ }^{\circ} \mathrm{C}$ for 48 hours to get constant weight, and weighted again. Shell total length, shell opening and operculum size measurements were performed. Individual biomass values were expressed in grams and correlated to length, in a weight-length relationship.

Semi-static acute toxicity tests with reference substances potassium chloride and sodium chloride, for checking $M$. tuberculata range of sensitivity were performed and results were expressed as CL(I)50-24 hours according to standardized procedures (USEPA, 1996; OECD, 2000). Concentrations tested based on literature data (USEPA, 1996; OECD, 2000) and checked by preliminary tests: $2.5 ; 5.0 ; 10.0 ; 15.0$ and $20.0 \mathrm{~g} \mathrm{~L}^{-1}$ for $\mathrm{NaCl}$; and $0.05 ; 0.1 ; 0.5 ; 1.0 ; 3.0$ and $5.0 \mathrm{~g} \mathrm{~L}^{-1}$ for $\mathrm{KCl}$.

For definitive toxicity-tests the organisms were exposed to test solutions for 24-h. They were kept at the same conditions used in the preliminary tests, without food. After 24-h the organisms were removed from test-recipients, test solutions were renewed, where they remained for another 24-h to recuperate. Dead organisms and survivors were counted at the end of 48 -h from the start of the test.

Acute toxicity test results were analyzed with the statistical program Trimmed Spearman-Karber (Hamilton et al., 1977) to estimate the median lethal concentration, LC(I) 50-24h. The range of sensitivity of the organism was considered as the interval between two standard deviations on each side of the LC(I) 50-24h mean value estimated in a series of experiments (USEPA, 1985).

To evaluate $M$. tuberculata temperature tolerance range, series of experiments were assembled with 10 replicates. The organisms were subjected to a range of temperatures $\left(15\right.$ to $\left.40{ }^{\circ} \mathrm{C}\right)$ in order to determine the tolerance limits of the species to this factor, other variables (total hardness and $\mathrm{pH}$ ) kept constant. This temperature range is the one where most organisms survive and have their active life (Schmidt-Nielsen, 1972). After a 10 days period of exposure the number of dead individuals was recorded.

\section{Results}

The individual growth of $M$. tuberculata was measured by the changes in the size of the shell over time. The presence of the macrophyte P. stratiotes was essential for the survival and growth of juveniles. The duration of the experiment did not evaluate the longevity of the organisms, and growth measurements were performed for 287 days. This period was sufficient to observe life cycle characteristics and determined the growth curve. Experimentally Livshits \& Fishelson (1983) reported that $M$. tuberculata snails become fertile when reaching $15-16 \mathrm{~mm}$ at the age of six months and continued to grow to attain a maximum length of $27 \mathrm{~mm}$, at a water temperature of $26-27^{\circ} \mathrm{C}$.

Moreover, in this work, the maximum values of lengths of shells found were 11.33 and $11.67 \mathrm{~mm}$. In Figure 1 are presented the growth curve of 


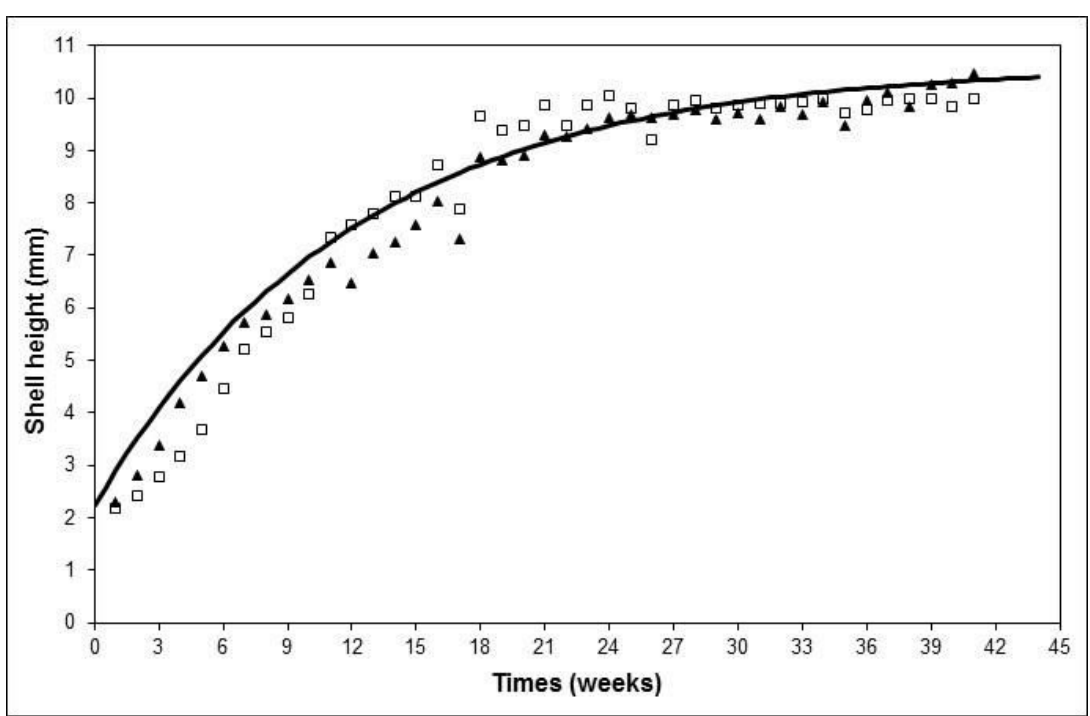

Figure 1. Curve of Melanoides tuberculata Müller, 1774 growth adjusted according to von Bertalanffy (1938) equation, under $25^{\circ} \mathrm{C}$, photoperiod of $12: 12$ hour light/dark and feed with macrophyte Pistia stratiotes L. 1753, in laboratory cultures and collected from fish tanks in CEPTA/ICMBio. The different points presented for the same date are replicas (Replica $1=\mathbf{\Delta}$; Replica $2=\square$ ).

the shell, in length, obtained for $M$. tuberculata. The theoretical maximum length $\left(\mathrm{L}_{\infty}\right)$ and the value of the rate of growth $(\mathrm{k})$ of $M$. tuberculata, according to the individual growth curve of the von Bertalanffy (1938), obtained in this work were $10.61 \mathrm{~mm}$ and 0.083 week $^{-1}$, respectively.

$M$. tuberculatus growth curve showed that growth increments were higher in the initial stages of the life cycle thus revealing an accelerated growth up to 147 days. In this period, the individuals reached the length, on average, of $9.58 \mathrm{~mm}$. This value is very close to the maximum length, $11.50 \mathrm{~mm}$. After this period, there was a decline in growth of the shell size being observed a decrease in the curve.

In addition, in replicate 1, individuals reached sexual maturity in 272 days measuring $9.97 \mathrm{~mm}$. For replica 2, sexual maturity was reached with 279 days and $10.28 \mathrm{~mm}$ in length. On average, M. tuberculata reached the primipara stage at the age of 275 days and $10.13 \mathrm{~mm}$ length under the laboratory conditions.

The dry weight-length relationship here obtained for M. tuberculata is shown in Figure 2. The greatest length was $175.0 \mathrm{~mm}$ and $0.16 \mathrm{~g}$ in the highest weight, of the smallest length recorded for the shell and weight were respectively, $70.0 \mathrm{~mm}$ and $0.01 \mathrm{~g}$. Also, it was found a high positive correlation ( $\left.r=0.9562, r^{2}=0.9144\right)$ between the increase of weight and the increase in length.

In Figures 3 and 4 are shown the relationships between shell length and the operculum size

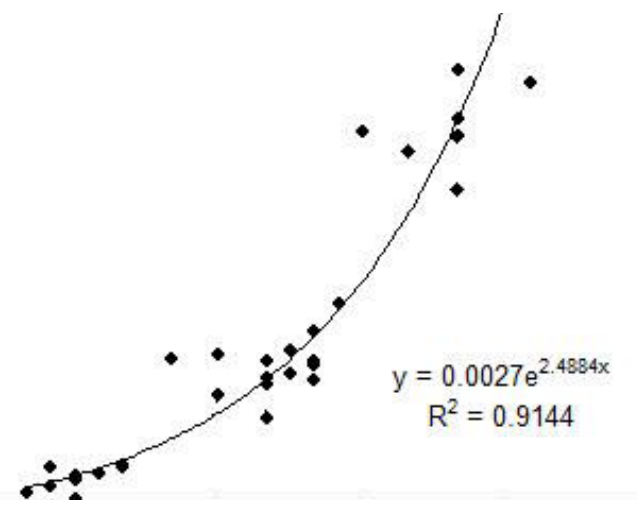

Figure 2. Relationship between the total dry weight and length of the shell to Melanoides tuberculata Müller, 1774 maintained in laboratory cultures and collected from fish tanks in CEPTA/ICMBio.

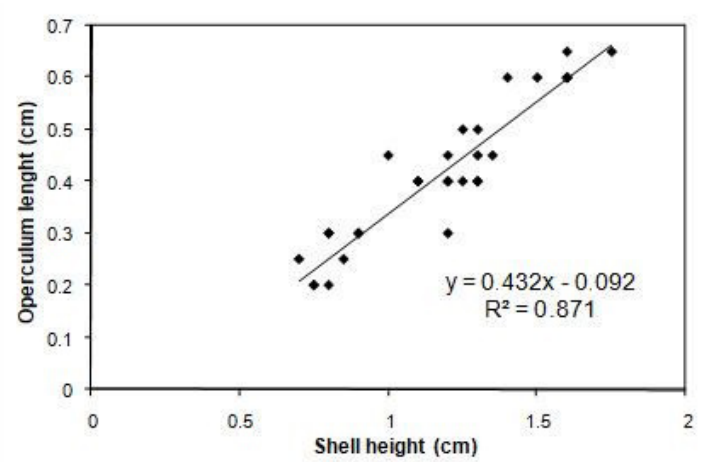

Figure 3. Relationship between the operculum size and length of the shell to Melanoides tuberculata Müller, 1774 maintained in laboratory cultures and collected from fish tanks in CEPTA/ICMBio. 
and between the length of the shell and the shell aperture. Both correlations had high coefficients of determination $\left(r^{2}\right)$, evidencing consistency of the obtained data. In Figure 5 it is shown a relationship between the length of the shell and the dry weight

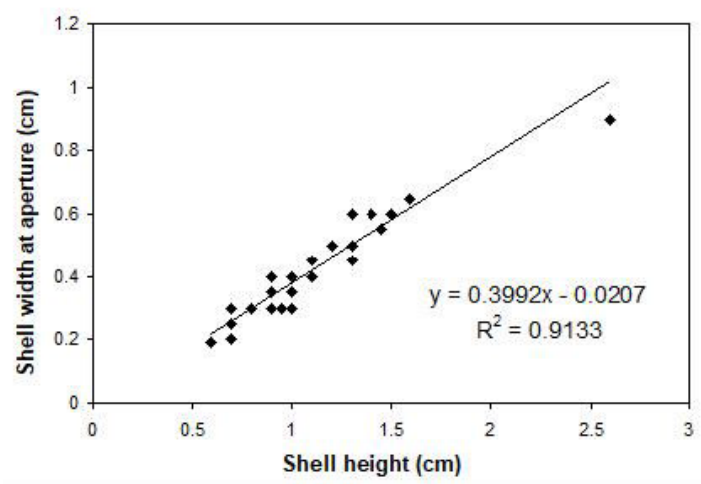

Figure 4. Relationship between the shell opening and the length of the shell of individuals Melanoides tuberculata Müller, 1774 maintained in laboratory cultures and collected from fish tanks in CEPTA/ICMBio.

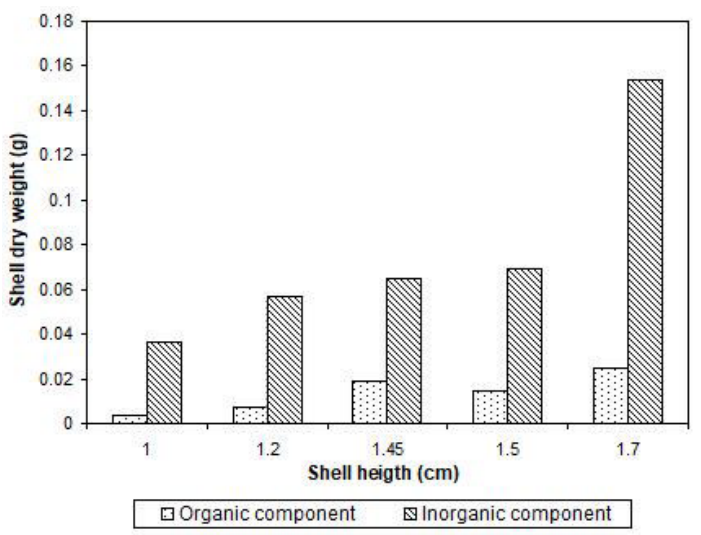

Figure 5. Dry weight of organic part and the mineral (shell) of different classes of size to Melanoides tuberculata Müller, 1774 maintained in laboratory cultures and collected from fish tanks in CEPTA/ICMBio.

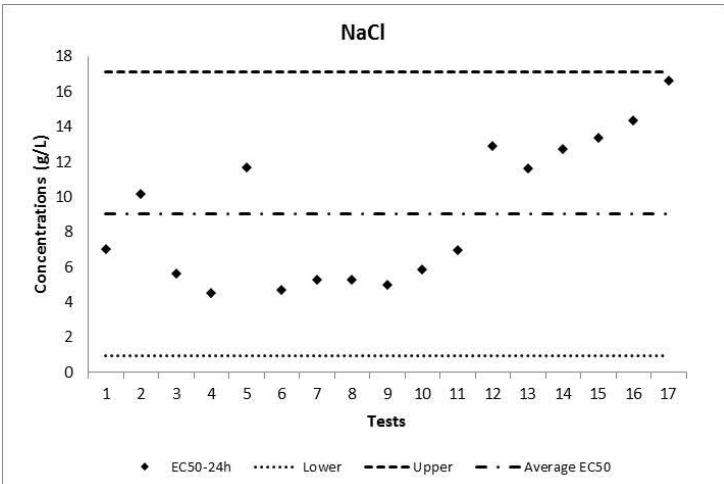

of mineral and organic fractions. It can be observed that the weight of the mineral fraction is greater than the weight of the organic fraction depending on the size. There was also a steady increase in the organic fraction as size increased

The results from toxicity tests with $M$. tuberculata exposed to $\mathrm{KCl}$ showed several individual reactions such as clouding of water, leakage of soft tissues, retraction of operculum and soft parts, and the release of the operculum. The range of sensitivity was 0.001 to $1.828 \mathrm{~g} \mathrm{~L}^{-1}$, with average $\mathrm{LC}(\mathrm{I}) 50-24 \mathrm{~h}$ of $0.701 \pm 0.563 \mathrm{~g} \mathrm{~L}^{-1}$. In the acute toxicity tests with $\mathrm{NaCl}$, the average $\mathrm{LC}(\mathrm{I}) 50-24 \mathrm{~h}$ was $9.053 \pm 4,042 \mathrm{~g} \mathrm{~L}^{-1}\left(0.968-17.138 \mathrm{~g} \mathrm{~L}^{-1}\right)$. The results of toxicity tests with the reference substances are summarized in Figure 6.

\section{Discussion}

While $M$. tuberculata may be described as a "fugitive" species, it is surprising that these animals have successfully colonized a wide variety of aquatic habitats over a considerable geographic range. Such similarity could indicate the "adaptiveness" of these snails and their "fugitive" species strategies. Indeed, parthenogenesis in these populations may enhance the retention of favorable adaptations and ensure their rapid spread through an expanding population. Adaptation of $M$. tuberculata to local conditions could be brought about because of environmental influences producing ecophenotypic modification (Fryer et al., 1983).

Although frequently overlooked by conservation biologists, variation in the growth rate of individuals can affect their chances of survival and reproduction, and therefore, is an important component of population dynamics. This type of information could be useful in determining the susceptibility of

Figure 6. Sensitivity range of the exotic invasive mollusk Melanoides tuberculata Müller, 1774, expressed as LC(I) 50-24h, when exposed to reference substances: sodium chloride ( $\mathrm{NaCl})$ and potassium chloride $(\mathrm{KCl})$. 
different populations to the effects of environmental stressors (Hastie et al., 2000).

Thus, as the process of growth is specific to any type of organism, it becomes important to establish patterns of growth for the species, with the aim of explaining relationship between growth of individuals and the environment in which they live (Nikolski, 1963).

Sobral \& Widdows (1997), studying the mussels Ruditapes decussatus, concluded that the measure of growth is a sensitive method to detect deviations from normal performance, and to assess environmental situations of real stress. Thus, the observations of growth under optimal conditions for cultivation in the laboratory can provide important information for management actions designed to take advantage of the susceptibility of different populations to environmental stresses.

In Table 1 was presented values of some parameters of $M$. tuberculata life cycle found in literature and those obtained in this study. The value of maximum shell length and hatching size (shell height, $\mathrm{mm}$ ) for $M$. tuberculata cultured in laboratory was nearby to that reported by other authors in tropical natural environments (Berry $\&$ Kadri, 1974; Livshits \& Fishelson, 1983; Dudgeon, 1986; Supian \& Ikhwanuddin, 2002). Thompson (1984) says that species typically reaches a shell length between 300 and $360 \mathrm{~mm}$.

According to Bedê (1992), the differences in the size of the newborn mollusks may be due the time that the embryos remain inside the reproductive bag of the females, located at the region hind the head, under the cloak, for three to five months before being released. In addition, the duration of post-embryonic development from birth until primipara is correlated with the population density (Livshits \& Fishelson, 1983).
Hastie et al. (2000) suggest four possible factors that strongly influence the growth of the shell and therefore explain its variation among different populations: the gene (genetic variation), the habitat physical (conditions of microhabitat), the chemistry of water $(\mathrm{pH}$, hardness and concentration of oxygen) and temperature. Thus, comparatively the shorter shell length observed in the present work may be related to the constant abiotic variables (temperature, hardness, $\mathrm{pH}$ ) in laboratory that is not observed in natural environments, as well as the lack of genetic variability of the organisms and the lack of food diversity offered to laboratory cultures.

Lévêque (1972) reports that $M$. tuberculata, in the Lake Chad, lives for more than one generation. Some studies, in natural conditions in the West Indies (Pointier et al., 1991, 1992) and certain laboratory data obtained to Pointier et al. (1992), suggested a life cycle for $M$. tuberculata less than five years. While Dudgeon (1986) and Berry \& Kadri (1974) suggested a lifetime from two to five years for M. tuberculata found in Hong Kong and Malaysia.

The measure of body size is a very important property, which serves as basis for assessing the rates of physiological processes in relation to stress by toxic substances and other factors (Rocha, 2003). However, only this measure cannot reveal the actual nutritional status of an individual, because often the organism may be in total state of starvation, and even then, make a body size similar to others as being on the same stage of life. The weight of individuals, however, can show large differences (Fonseca, 1991).

Therefore, the weight, expressed as fresh weight, dry weight or weights of individual elements such as $\mathrm{C}, \mathrm{N}$ and $\mathrm{P}$, used to express the biomass, can be a suitable tool and may well prove the nutritional

Table 1. Comparison of life cycle parameters of Melanoides tuberculata Müller, 1774 populations in Tchad lake, Africa (data from Lévêque, 1972), in Malaysia (data from Berry \& Kadri, 1974), in Israel and the Sinai Peninsula (data from Livshits \& Fishelson, 1983), in Hong Kong (data from Dudgeon, 1986), in Pampulha reservoir, Minas Gerais, Brazil (Bedê, 1992), in Borneo (Supian \& Ikhwanuddin, 2002) and in São Paulo, Brazil (this study).

\begin{tabular}{|c|c|c|c|c|c|c|c|c|}
\hline Life Cycle Parameters & $\begin{array}{l}\text { Lévêque } \\
\text { (1972) }\end{array}$ & $\begin{array}{c}\text { Berry } \\
\text { \& Kadri } \\
\text { (1974) }\end{array}$ & $\begin{array}{c}\text { Livshits } \\
\& \\
\text { Fishelson } \\
(1983) \\
\end{array}$ & $\begin{array}{c}\text { Thompson } \\
\text { (1984) }\end{array}$ & $\begin{array}{l}\text { Dudgeon } \\
(1986)\end{array}$ & $\begin{array}{c}\text { Bedê } \\
(1992)\end{array}$ & $\begin{array}{c}\text { Supian \& } \\
\text { Ikhwanuddin } \\
(2002)\end{array}$ & $\begin{array}{l}\text { This } \\
\text { study }\end{array}$ \\
\hline $\begin{array}{l}\text { Size at first reproduction } \\
\text { (shell height, } \mathrm{mm} \text { ) }\end{array}$ & - & $8.3-9.5$ & $15.0-16.0$ & - & $10.8-11.5$ & - & - & $\begin{array}{l}9.97- \\
10.28\end{array}$ \\
\hline $\begin{array}{l}\text { Age at first reproduction } \\
\text { (days) }\end{array}$ & 150 & $100-200$ & 180 & - & $90-120$ & 710 & - & $272-279$ \\
\hline $\begin{array}{l}\text { Hatching size } \\
\text { (shell height, } \mathrm{mm} \text { ) }\end{array}$ & - & $2.6-3.4$ & $1.5-2.0$ & - & $2.2-3.4$ & - & - & $\begin{array}{c}2.24 \pm \\
0.09\end{array}$ \\
\hline $\begin{array}{l}\text { Maximum size } \\
\text { (shell height, } \mathrm{mm} \text { ) }\end{array}$ & - & 340 & 270 & $300-360$ & 300 & - & 250 & 150 \\
\hline Maximum age (years) & - & $3-5$ & - & - & $2-2.5$ & - & - & - \\
\hline
\end{tabular}


status (Fonseca, 1991). The weight-length obtained in this work indicates that there is a proportional relationship between the shell growth and increase in weight. Therefore, we could say that individuals of $M$. tuberculata well acclimatized in this study.

Moreover, it was observed that from the shell length of $1.2 \mathrm{~cm}$ there was a larger increase in the organic portion of individuals. According to Dudgeon (1986), the initial growth of $M$. tuberculata is characterized by the development of a larger amount of periostracum (over $50 \%$ of the weight of the shell-free), but with the achievement of sexual maturity, the increase of relative weight periostracum declines and dry organic matter free of ladle increases in class of greater size. Abilio (1997) also noted that a larger increase of organic matter in the total dry weight of individuals of $M$. tuberculata in three reservoirs in Paraíba.

Thus, M. tuberculata showed stronger growth in the juvenile stage because in sexual maturity individuals reduced investment in growth to invest in reproduction. In this study, after 24 weeks, we observed that the curve of growth began to stabilize, reaching a decrease in the same period in which individuals of $M$. tuberculata reached sexual maturity. This huge investment in reproduction by individuals in classes of greater size also results in a high mortality rate in this group and a smaller proportion of adults in the population (Dudgeon, 1986).

Livshits \& Fishelson (1983) argued that individuals smaller than $10.0 \mathrm{~mm}$ can reproduce itself and the adults reach its maximum capacity of reproduction with $20.0 \mathrm{~mm}$. In literature is reported that the age and size of individuals in the first reproduction were 100 to 720 days old and from 8.3 to $16.0 \mathrm{~mm}$, respectively, for $M$. tuberculata. These results corroborate the idea that to cultivate M. tuberculata in laboratory is viable.

The curve of growth of $M$. tuberculata in this paper shows slow a growth and a long life expectancy in laboratory conditions. In juvenile stage, the specie investment in shell growth is more pronounced until the sexually mature phase when the investing more in reproduction. This increase was $0.17 \pm 0.21 \mathrm{~mm}$ per week. The parameters of the logistics curve of growth for $M$. tuberculata, obtained in this study, revealed, however, values of growth rate $(\mathrm{k})$ and theoretical maximum length $\left(\mathrm{L}_{\infty}\right)$ equal to 3.98 years $^{-1}$ and $10.61 \mathrm{~mm}$, respectively. Considering that the reproductive period of $M$. tuberculata is closely related to individual size (Berry \& Kadri, 1974; Dudgeon, 1986) is of fundamental importance to know what the growth rates of exotic species in Brazilian freshwater.

The rapid growth rate of $M$. tuberculata supports the idea of the potential as invasive species, because these gastropods presented values of $\mathrm{k}$ larger than other mollusks as shown in Table 2. Also, because of their sexual maturity is closely related to the size of the individual (Berry \& Kadri, 1974; Dudgeon, 1986), they could compete with native species of slower growth, due their reproductive process with the highest growth rates $(\mathrm{k})$ and lower life expectancy.

In this study, $M$. tuberculata kept in the laboratory showed a narrow range of temperature tolerance, surviving in the range $16{ }^{\circ} \mathrm{C}$ to $37^{\circ} \mathrm{C}$. Lévêque (1972), at Lake Chad, and Bedê (1992), at reservoir of Pampulha (MG), observed increased growth and production of $M$. tuberculata at higher temperatures, in the range from $29{ }^{\circ} \mathrm{C}$ to $33^{\circ} \mathrm{C}$. That reinforce the idea of $M$. tuberculata as hot-stenothermal specie.

Odum (1983) assert that, in general, the upper limits become faster than the lower critical limits. However, the most species seem to work more efficiently close to the upper limits of their tolerance ranges. This seems the case of $M$. tuberculata, which not tolerated low temperatures, although, has accepted moderate temperatures of approximately $16^{\circ} \mathrm{C}$.

Table 2. Parameters of the von Bertalanffy equation ( $\mathrm{k}$, growth rate, and $\mathrm{L}_{\infty}$, theoretical maximum length of the shell) of different mollusks (compiled from the literature) and the values obtained in this study to Melanoides tuberculata Müller, 1774.

\begin{tabular}{lccc}
\hline \multicolumn{1}{c}{ Species } & \multicolumn{2}{c}{ von Bertalanffy parameters } & Authors \\
\cline { 2 - 3 } & $\mathbf{k}\left(\right.$ year $\left.^{-1}\right)$ & $\mathbf{L}_{\infty}(\mathbf{c m})$ & Marenzi \& Branco (2005) \\
\cline { 1 - 3 } $\begin{array}{l}\text { Perna perna Linnaeus, 1758 } \\
\text { (Mytilidae, Bivalvia) }\end{array}$ & 2.29 & 9.0 & Boltovskoy \& Cataldo (1999) \\
$\begin{array}{l}\text { Limnoperma fortune Dunker, 1857 } \\
\text { (Mytilidae, Bivalvia) }\end{array}$ & 1.0 & 3.5 & Hastie et al. (2000) \\
$\begin{array}{l}\text { Margaritifera margaritifera Linnaeus, 1758 } \\
\text { (Margaritiferidae, Bivalvia) }\end{array}$ & 0.063 & 11.25 & This study \\
$\begin{array}{l}\text { Melanoides tuberculata Müller, 1774 } \\
\text { (Thiaridae, Gastropoda) }\end{array}$ & 3.98 & 1.06 & \\
\hline
\end{tabular}


This fact could explain why the individuals of M. tuberculata cultivated in the laboratory at a constant temperature of $25^{\circ} \mathrm{C}$, when compared with individuals observed in field at higher temperatures, presented longer development times. Besides primipara in laboratory was approximately double the found in the literature. According to Elkarmi \& Ismail (2007), studying two populations of $M$. tuberculata from different locations (hot springs and freshwater pools), they observed that higher temperatures can increase metabolic rates and, therefore, reduce life expectancy. This would explain how temperature conditions affected the growth and development of $M$. tuberculata specimens when comparing data from individuals grown in the laboratory with the results collected and observed in the field, where there are higher temperature variations.

In addition, these gastropods feed mainly to periphyton communities, organic particles and bacteria deposited on the sediment (Dudgeon, 1989; Pointier, et al., 1991). The activity of these gastropods can be controlled by luminosity. During the day, these mollusks bury themselves in the sediment or hide under plants and stones; when dark, they go out to look for food (Livshits \& Fishelson, 1983). In captivity, M. tuberculata shows the same behavior: during the day, these gastropods huddled at corner of the aquarium or buried themselves at sand, and with the decrease in light, they increased their activity, huddling on the floor and climbing the aquarium walls.

Thus, lotic environments would be more suitable for the development of $M$. tuberculata. Paula et al. (2017), studying different aquatic systems at hydrographic basin of Sorocaba river, SP, observed that degraded and silted environments had a greater abundance of these mollusks. Other authors (Marco Junior, 1999; Martins-Silva \& Barros, 2001) characterized these environments as important areas in the colonization of $M$. tuberculata.

There were differences in sensitivity of M. tuberculata to the different salts. The biological aspects of $M$. tuberculata evaluated in this study allow us to conclude that, in accordance with the speculation of Pennak (1989) KCl may be even much more toxic than $\mathrm{NaCl}$, standardized reference substance internationally.

The wide sensitivity range of $M$. tuberculata $\left(0.968-17.138 \mathrm{~g} \mathrm{~L}^{-1}\right)$ indicates that this snail is resistant to $\mathrm{NaCl}$, supporting wide variations in salinity. Russo (1973) and Roessler et al. (1977) found $M$. tuberculata both freshwater and estuarine waters in south Florida, USA. Roessler et al.
(1977) recorded a high number of $M$. tuberculata in waters with salinity greater than $30 \mathrm{ppm}$ of $\mathrm{NaCl}$. Thus, the acceptable values by this species to saline environment suggest the possibility of their introduction through ballast water.

All the variables analyzed support the information on the invasive potential of $M$. tuberculata: temperature, growth curve, reproduction, $\mathrm{NaCl}$ tolerance. Thus, the great variability in the LC50 and the wide temperature tolerance range in this study may represent the high adaptability of this mollusk to environmental factors.

In addition, its morphology with the presence of the operculum is an adaptive advantage to the resistance of this species to disturbances in its habitat, as may have been observed during ecotoxicity tests. Considering the lack of substantial taxonomic and ecological studies on the nature and exotic fauna of freshwater mollusks in Brazil and the environmental impact caused by exotic species. Such research is of particular interest, in view of the abundance of $M$. tuberculata in tropical freshwater.

\section{Acknowledgements}

The preparation of this work has had the financial resources of the Project PROBIO (MMA/CNPq/WB/GEF) and the subproject "Monitoring and Development of Technology for the Management of Exotic Species in Freshwaters." The authors are also grateful to CNPq/EESC/USP program for the scholarship provided to the first author.

\section{References}

ABÍLIO, FJ.P. Aspectos bio-ecológicos da fauna malacológica, com ênfase a Melanoides tuberculata Müller, 1774 (Gastropoda, Thiaridae) em corpos aquáticos do Estado da Paraíba [Dissertação de Mestrado em Ciências Biológicas]. João Pessoa: Universidade Federal da Paraíba, 1997, $151 \mathrm{p}$.

BEDÊ, L.C. Dinâmica populacional de Melanoides tuberculata (Prosobranchia Thiaridae) no reservatório de Pampulha, Belo Horizonte, MG, Brasil [Dissertação de Mestrado em Ecologia]. Belo Horizonte: Universidade Federal de Minas Gerais, 1992, 112 p.

BERRY, A.J. and KADRI, H. Reproduction in the Malayan freshwater cerithiacean gastropod Melanoides tuberculata. Journal of Zoology, 1974, 172(3), 369381. http://dx.doi.org/10.1111/j.1469-7998.1974. tb04113.x.

BOAVENTURA, M.F., FERNANDEZ, M.A., THIENGO, S.C., SILVA, R.F. and MELO, A.L. Formas larvais de Trematoda provenientes de gastrópodes límnicos de microregião Rio de Janeiro, sudeste do Brasil. Lundiana, 2002, 3(1), 45-49. 
BOGÉA, T., CORDEIRO, F.M. and GOUVEIA, J.S. Melanoides tuberculata (Gastropoda: Thiaridae) as intermediate host of heterophydae (Trematoda: Digenea) in Rio de Janeiro metropolitan area, Brazil. Revista do Instituto de Medicina Tropical de São Paulo, 2005, 47(2), 87-90. http://dx.doi.org/10.1590/ S0036-46652005000200005. PMid:15880219.

BOLTOVSKOY, D. and CATALDO, D.H. Population dynamics of Limnoperna fortunei, an invasive fouling mollusk, in the lower Paraná river (Argentina). Biofouling, 1999, 14(3), 255-263. http://dx.doi. org/10.1080/08927019909378417.

CALOW, P. Adaptational aspects of growth and reproduction in Lymnaea peregra from exposed and sheltered aquatic habitats. Malacologia, 1981, 21, 5-13.

CIVEYREL, L. and SIMBERLOFF, D. A tale of two snails: is the cure worse than the disease? Biodiversity and Conservation, 1996, 5(10), 1231-1252. http:// dx.doi.org/10.1007/BF00051574.

DORNFELD, C.B., PAMPLIN, P.A.Z., ESPÍNDOLA, E.L.G., ALVES, R.G. and ROCHA, O. Composição, distribuição e mudanças temporais da fauna de invertebrados bentônicos do reservatório de Salto Grande (Americana, SP). In: E.L.G. ESPÍNDOLA, M.A. LEITE and C.B. DORNFELD, eds. Reservatório de Salto Grande (Americana, SP): caracterização, impactos e propostas de manejo. 1. ed. São Carlos: RiMa, 2004, pp. 221-238.

DUDGEON, D. Ecological strategies of Hong Kong Thiaridae (Gastropoda: Prosobranchia). Malacological Review, 1989, 22, 39-53.

DUDGEON, D. The lyfe cycle, population dynamics and productivity of Melanoides tuberculata (Müller, 1774) (Gastropoda, Posobranchia, Thiaridae) in Hong Kong. Journal of Zoology, 1986, 208(1), 3753. http://dx.doi.org/10.1111/j.1469-7998.1986. tb04707.x.

ELKARMI, A.Z. and ISMAIL, N.S. Growth models and shell morphometrics of two populations of Melanoides tuberculata (Thiaridae) living in hot springs and freshwater pools. Journal of Limnology, 2007, 66(2), 90-96. http://dx.doi.org/10.4081/ jlimnol.2007.90.

FERNANDEZ, M.A., THIENGO, S.C. and SIMONE, L.R.L. Distribution of the introduced freshwater snail Melanoides tuberculata (Gastropoda: Thiaridae) in Brazil. The Nautilus, 2003, 117(3), 78-82.

FONSECA, A.L. Biologia das especies Dalphnia laevis Ceriodaphnia silvestrii (Crustacea, Cladocera) e Poecilia reticulata (Pisces, Poecilidae) e comportamento destes em testes de toxicidade aquatica com efluentes industriais [Dissertação de Mestrado em Engenharia Hidráulica e Saneamento]. São Carlos: Escola de Engenharia de São Carlos, Universidade de São Paulo, 1991, 210 p.

FRYER, G., GREENWOOD, P.H. and PEAKE, J.F. Punctuated equilibria, morphological stasis and the paleontological documentation of speciation: a biological appraisal of a case history in an African lake. Biological Journal of the Linnean Society. Linnean Society of London, 1983, 20(2), 195-205. http:// dx.doi.org/10.1111/j.1095-8312.1983.tb00363.x.

GIOVANELLI, A., SILVA, C.L., MEDEIROS, L. and VASCONCELLOS, M.C. Interaction between the intermediate host of Schistosomiasis in Brazil Biomphalaria glabrata (Planorbidae) and a possible competitor Melanoides tuberculata (Thiaridae) I. Laboratory experiments. Memórias do Instituto Oswaldo Cruz, 2002, 96(1), 123-125. http:// dx.doi.org/10.1590/S0074-02762001000100014. PMid: 11285483.

GUIMARÃES, C.T., SOUZA, C.P. and SOARES, D.M. Possible competitive displacement of planorbids by Melanoides tuberculata in Minas Gerais, Brazil. Memórias do Instituto Oswaldo Cruz, 2001, 96, 173176, Supplement. http://dx.doi.org/10.1590/S007402762001000900027 . PMid:11586446.

HAMILTON, M.A., RUSSO, R.C. and THURSTON, R.V. Trimed Sperman-Karber method for estimating median lethal concentration in toxicity bioassays. Environmental Science \& Technology, 1977, 11(7), 714-719. http://dx.doi.org/10.1021/es60130a004.

HASTIE, L.C., YOUNG, M.R. and BOON, F.J. Growth characteristics of freshwater pearl mussels, Margaritifera margaritifera (L.). Freshwater Biology, 2000, 43(2), 243-256. http://dx.doi.org/10.1046/ j.1365-2427.2000.00544.x.

LÉVÊQUE, C. Mollusques benthiques du lac Tchad: écologie, etude des peuplements et estimation des biomasses. Cahiers de l'Office de la Recherche Scientifique et Technique Outre-Mer., Série Hydrobiologie, 1972, 6(1), 3-45.

LIVSHITS, G. and FISHELSON, L. Biology and reproduction of the freshwater snail Melanoides tuberculata (Gastropoda: Posobranchia) in Israel. Israel Journal of Zoology, 1983, 32, 21-35.

MADSEN, H. and FRANDSEN, F. The spread of freshwater snails including those of medical and veterinary importance. Acta Tropica, 1989, 46(3), 139-146. http://dx.doi.org/10.1016/0001706X(89)90030-2. PMid:2566266.

MALEK, E.A. and CHENG, T.C. Medical and economic malacology. New York: Ed. Academic Press, 1974, $382 \mathrm{p}$.

MALEK, E.A. Snails transmitting parasitic diseases. Boca Raton: CRC Press, 1980, 134 p.

MARCO JUNIOR, P. Invasion by the introduced aquatic snail Melanoides tuberculata (Müller, 1774) (Gastropoda: Prosobranchia: Thiaridae) of the Rio Doce State Park, Minas Gerais, Brazil. Studies on Neotropical Fauna and Environment, 1999, 34(3), 186-189. http://dx.doi.org/10.1076/ snfe.34.3.186.8908.

MARENZI, A.W.C. and BRANCO, J.O. O mexilhão Perna perna (Linnaeus) (Bivalvia, Mytilidae) em cultivo na Armaçấo do Itapocoroy, Santa 
Catarina, Brasil. Revista Brasileira de Zoologia, 2005, 22(2), 394-399. http://dx.doi.org/10.1590/S010181752005000200013.

MARTINS-SILVA, M. and BARROS, M. Ocurrence and distribution of freshwater molluscs in the Riacho Fundo Creek Basin, Brasília, Brazil. Revista de Biología Tropical, 2001, 49(3-4), 865-870. PMid:12189816.

MEAD, A.R. Economic malacology: with particular reference to Achatina fulica. In: Fretter, V. \& Peake, J. (eds). Pulmonates. London: Academic Press, 1979, 150p.

NIKOLSKI, G.V. The ecology offishes. London: Academic Press, 1963, $352 \mathrm{p}$.

ODUM, E.P. b. Interciência, 1983, 385p.

ORGANISATION FOR ECONOMIC COOPERATION AND DEVELOPMENT - OECD. OECD guideline for the testing of chemicals: fish, juvenile growth test. Paris: OECD, 2000, 16 p. vol. 215.

PAMPLIN, P.A.Z. Avaliação da qualidade ambiental da represa de Americana (SP-Brasil) com ênfase no estudo da comunidade de macroinvertebrados bentônicos e parâmetros exotoxilógicos [Dissertação de Mestrado em Ciências da Engenharia Ambiental]. São Carlos: Escola de Engenharia de São Carlos, Universidade de Sáo Paulo, 1999, 111 p.

PAULA, C.M., VAZ, A.A., VAZ, A.A., PELIZARI, G.P., ROBAYO, H.M.S., GARCIA, T.D., AVELINO, D., ZACARIN, G.G. and SMITH, W.S. Ocorrência de um molusco invasor (Melanoides tuberculata, Müller, 1774), em diferentes sistemas aquáticos da bacia hidrográfica do Rio Sorocaba, SP, Brasil. Revista Ambiente \& Água, 2017, 12(5), 829-841. http:// dx.doi.org/10.4136/ambi-agua.1971.

PENNAK, R.W. Fresh-water invertebrates of the United States: Protozoa to Mollusca. USA: John Wiley \& Sons, 1989, pp. 541-5683. vol. 24.

POINTIER, J.P., DELAY, B., TOFFART, J.L., LÉFÊVRE, M. and ROMERO-ALVAREZ, R. Life history traits of three morphs of Melanoides tuberculata (Gastropoda, Thiaridae), an invading snail in French West Indies. The Journal of Molluscan Studies, 1992, 58(4), 415-423. http://dx.doi. org $/ 10.1093 /$ mollus $/ 58.4 .415$.

POINTIER, J.P., THÉRON, A. and BOREL, G. Ecology of the introduced snail Melanoides tuberculata (Gastropoda: Thiaridae) in relation to Biomphalaria glabrata in the marshy forest zone of Guadaloupe, French West Indies. The Journal of Molluscan Studies, 1993, 59(4), 421-428. http:// dx.doi.org/10.1093/mollus/59.4.421.

POINTIER, J.P., TOFFART, J.L. and LÉFÊVRE, M. Life tables of freshwater snails of the genus Biomphalaria (B. glabrata, B. alesandrina, B. straminea) and one of its competitors Melanoides tuberculata under laboratory conditions. Malacologia, 1991, 33, 43-54.

ROCHA, O. Técnicas de manejo de espécies exóticas e alóctones de peixes com ênfase nas interaçōes tróficas das larvas e alevinos destas espécies com organismos zooplanctônicos. São Carlos: Plano de Pesquisa, 2003, 20 p.

ROESSLER, M.A., BEARDSLEY, G.L. and TABB, D.C. New records of the introduced snail, Melanoides tuberculata (Mollusca: Thiaridae) in south Florida. Florida Scientist, 1977, 40(1), 87-94.

RUSSO, T.N. Discovery of the gastropod snail Melanoides (Thiara) tuberculata (Müller) in Florida. Florida Scientist, 1973, 36(2-4), 212-213.

SCHMIDT-NIELSEN, K. Fisiologia animal. São Paulo: Edgard Blücher, 1972, pp. 43-56.

SOBRAL, P. and WIDDOWS, J. Effects of elevated temperatures on the scope for growth and resistance to air exposure of the clam Ruditapes decussatus (L), from southern Portugal. Scientia Marina, 1997, 61(2), 163-171.

SUPIAN, Z. and IKHWANUDDIN, A.M. Population dynamics of freshwater mollusks (Gastropoda: Melanoides tuberculata) in Crocker Range Park, Sabah. ASEAN Review of Biodiversity and Environmental Conservation, 2002, 1, 1-9.

SURIANI, A.L., FRANCA, R.S. and ROCHA, O. A malacofauna bentônica das represas do médio rio Tietê (SP) e uma avaliação ecológicadas espécies exóticas invasoras, Melanoides tuberculata (Muller) e Corbicula fluminea (Muller). Revista Brasileira de Zoologia, 2007, 24(1), 21-32. http://dx.doi. org/10.1590/S0101-81752007000100003.

THOMPSON, F.G. The freshwater snails of Florida: a manual for identification. Gainesville: University of Florida Press, 1984, 94 p.

UNITED STATES ENVIRONMENTAL PROTECTION AGENCY - USEPA. OPPTS 885.4200: microbial pesticide test guidelines: freshwater fish testing, Tier I. Washington: USEPA, 1996, 4 p.

UNITED STATES ENVIRONMENTAL PROTECTION AGENCY - USEPA. SEPA/600/485/014: short-term methods for estimating the chronic toxicity of effluents and receiving waters to freshwater organisms. Cincinnati, OH: USEPA, 1985, $162 \mathrm{p}$.

VAZ, J.F., TELES, H.M.S., CORREA, M.A. and LEITE, S.P.S. Ocorrência no Brasil de Thiara (Melanoides tuberculata Müller, 1974) (Gastropoda, Prosobranchia), primeiro hospedeiro intermediário de Clonorchis sinensis (Cobbold, 1875) (Trematoda, Plathyhelmintes). Revista de Saude Publica, 1986, 20(4), 318-322. http://dx.doi.org/10.1590/S003489101986000400008. PMid:3554478.

VON BERTALANFFY, L. A quantitative theory of organic growth. Human Biology, 1938, 10(2), 181-213.

Received: 29 January 2019 Accepted: 26 May 2020

Associate Editor: André Megali Amado. 